\title{
Genotoxicity Studies Performed in the Ecuadorian Population
}

\author{
César Paz-y-Miño, Nadia Cumbal, and María Eugenia Sánchez \\ Instituto de Investigaciones Biomédicas, Facultad de Ciencias de la Salud, Universidad de las Américas, \\ Ave. de los Granados y Colimes Quito, 1712842, Ecuador \\ Correspondence should be addressed to César Paz-y-Miño, cpazymino@udla.edu.ec
}

Received 3 February 2011; Revised 25 November 2011; Accepted 5 December 2011

Academic Editor: Mark Berneburg

Copyright ( 12012 César Paz-y-Miño et al. This is an open access article distributed under the Creative Commons Attribution License, which permits unrestricted use, distribution, and reproduction in any medium, provided the original work is properly cited.

\begin{abstract}
Genotoxicity studies in Ecuador have been carried out during the past two decades. The focuses of the research were mainly the area of environmental issues, where the populations have been accidentally exposed to contaminants and the area of occupational exposure of individuals at the workplace. This paper includes studies carried out in the population of the Amazon region, a zone known for its rich biodiversity as well as for the ecological damage caused by oil spills and chemical sprayings whose consequences continue to be controversial. Additionally, we show the results of studies comprised of individuals occupationally exposed to toxic agents in two very different settings: flower plantation workers exposed to pesticide mixtures and X-ray exposure of hospital workers. The results from these studies confirm that genotoxicity studies can help evaluate current conditions and prevent further damage in the populations exposed to contaminants. As such, they are evidence of the need for biomonitoring employers at risk, stricter law enforcement regarding the use of pesticides, and increasingly conscientious oil extraction activities.
\end{abstract}

\section{Introduction}

Genotoxicity is a collective term that refers to any process that affects the structural integrity of DNA [1]. This multidisciplinary field of research aims to detect compounds capable of causing DNA damage in hopes of understanding the biological consequences of genotoxic agents and their involvement in the alteration of the molecular mechanisms of the genetic material [2]. These consequences can eventually lead to carcinogenic processes [3]. Over the past century, industrialization and globalization of the western hemisphere lead to the high volume production of different chemicals and complex preparations that are still currently released into the environment [4]. Living organisms are increasingly being exposed to genotoxic agents whose growing presence in the biosphere can substantially harm the population [5]. Activities such as fuel extraction and glyphosate spraying in the Amazon region of Ecuador are the two most controversial environmental health issues in the nation and are still considered as latent threats whose consequences continue to be studied $[6,7]$. Agriculture in Ecuador is the second most important productive activity that contributes to national income [8]. However, the lack of regulation regarding pesticide use and occupational safety pose a significant threat to the workers' health [9]. Additionally, various studies have focused on individuals exposed to radiation in the workplace, such as medical radiation workers constantly exposed to ionizing radiation that has well-known DNA-damaging effects [10-12]. The present paper intends to show a summary on the work carried out in Ecuador for the past two decades in the field of genotoxicity. All the cytogenetic studies have been performed on blood lymphocytes and the results obtained refer only to somatic mutations. The studies have included cytogenetic findings, such as the ones presented in Table 1 as well as molecular results which are shown in Table 2.

\section{Glyphosate Genotoxicity Studies}

The northeastern Ecuadorian border underwent the aerial spraying of an herbicide mix during the period of 20022007 and was supported by the Colombian government [13]. The Roundup mix presumably contained high doses of glyphosate plus a surfactant known as polyethoxylated tallowamine (POEA) and the adjuvant Cosmoflux 411F [14]. 
TABLE 1: Cytogenetic findings in genotoxicity studies.

\begin{tabular}{|c|c|c|}
\hline \multirow{2}{*}{ Glyphosate } & Paz-y-Miño et al. [6] & Comet assay: $35.5 \mu \mathrm{m}$ DNA migration for exposed, $25.94 \mu \mathrm{m}$ for controls. \\
\hline & Paz-y-Miño et al. [13] & All the studied population showed low or no chromosomal fragility. \\
\hline \multirow{2}{*}{ Other pesticides } & Paz-y-Miño et al. $[9,10,93]$ & Chromosomal aberrations: $20.59 \%$ in exposed and $2.73 \%$ in controls. \\
\hline & Paz-y-Miño et al. [55] & $\begin{array}{l}\text { Comet assay: } 31.58 \mu \mathrm{m} \text { DNA migration for exposed, } 25.94 \mu \mathrm{m} \text { for controls. } \\
\text { Chromosomal aberrations: } 5.48 \% \text { in exposed and } 0.45 \% \text { in controls. }\end{array}$ \\
\hline \multirow[t]{2}{*}{ Hydrocarbons } & Paz-y-Miño et al. [7] & $\begin{array}{l}\text { Chromosomal aberrations: } 20 \% \text { in exposed and } 1-2 \% \text { in controls. } \\
12 \% \text { type A DNA damage and } 1 \% \text { type E DNA damage in exposed group while } 81 \% \\
\text { type A and } 0 \% \text { type E in controls. }\end{array}$ \\
\hline & Paz-y-Miño et al. [88] & $\begin{array}{l}48.8 \% \text { type A DNA damage and } 0.1 \% \text { type E DNA damage in exposed group while } \\
67.9 \% \text { type } \mathrm{A} \text { and } 0 \% \text { type } \mathrm{E} \text { in controls. }\end{array}$ \\
\hline \multirow{4}{*}{ Radiation } & Paz-y-Miño et al. [102] & $\begin{array}{l}\text { Chromosomal aberrations: } 29 \% \text { in exposed, } 26.0 \% \text { in the followup, and } 3.5 \% \text { in } \\
\text { controls. }\end{array}$ \\
\hline & Paz-y-Miño et al. [112] & $\begin{array}{l}12.6 \% \text { metaphases with telomeric associations in the exposed smoker group; } 6.0 \% \text { TA } \\
\text { in exposed nonsmokers; } 9.0 \% \text { in unexposed smokers and } 0.1 \% \text { TA in control group. }\end{array}$ \\
\hline & Paz-y-Miño et al. $[9,10,93]$ & $\begin{array}{l}\text { Comet assay: } 26.55 \mu \mathrm{m} \text { DNA migration; mean chromosomal aberrations without gaps: } \\
\text { 5.39\% }(r=0.50, P<0.05) \text {. Mean chromosomal aberrations including gaps: } 12.08 \% \\
(r=0.78, P<0.01)\end{array}$ \\
\hline & Muñoz et al. [128] & $\begin{array}{l}\text { Comet assay: } 29.08 \mu \mathrm{m} \text { DNA migration for exposed group, } 25.91 \mu \mathrm{m} \text { for controls. } \\
\text { Chromosomal aberrations: } 50 \% \text { in exposed, } 26.0 \% \text { in the followup, and } 4 \% \text { in controls. }\end{array}$ \\
\hline
\end{tabular}

TABLE 2: Molecular findings in genotoxicity studies.

\begin{tabular}{|c|c|c|}
\hline Glyphosate & Paz-y-Miño et al. [13] & $\begin{array}{l}\text { Regarding the GSTP1 Ile105Val polymorphism, the frequency of the Val } \\
\text { allele was higher in exposed individuals ( } 0.48) \text { than control individuals } \\
\text { (0.28). The Val/Val variant represented a } 4.88 \text {-fold risk of acquiring } \\
\text { detoxification problems, whereas the combination of the Ile/Val and } \\
\text { Val/Val alleles was associated with a 2.6-fold risk of presenting a GSTP1 } \\
\text { gene dysfunction. As for the GPX-1 Pro198Leu polymorphism, the Leu } \\
\text { allele had a higher frequency in exposed individuals }(0.41) \text {, unlike control } \\
\text { individuals (0.32). The Leu/Leu variant was associated with an 8.5-fold risk } \\
\text { of having problems in the function of the GPX-1 gene. }\end{array}$ \\
\hline Other pesticides & Paz-y-Miño et al. [55] & $\begin{array}{l}\text { The level of damage was not significantly influenced by genetic } \\
\text { polymorphisms of the CYP } 1 A 1 \text { gene in the studied population. }\end{array}$ \\
\hline Hydrocarbons & Paz-y-Miño et al. [7] & $\begin{array}{l}\text { As far as the } M S H 2 \text { gene is concerned, there is a relation between } \\
\text { polymorphisms of the exon } 13 \text { and the DNA damage evaluated in the } \\
\text { individuals exposed to hydrocarbons }(P<0.001) \text {, the study of the } C Y P 1 A 1 \\
\text { gene found no relation between its polymorphisms and having greater } \\
\text { susceptibility to DNA damage. }\end{array}$ \\
\hline
\end{tabular}

Glyphosate is an effective organophosphorous herbicide used worldwide $[15,16]$ known to cause variable levels of toxicity in different organisms, such as the alteration of metabolic pathways, cytotoxicity in humans, metamorphosis alterations in amphibians, and abnormal development of sea urchin eggs [17-22]. Such reports add to the already numerous concerns over the compound's many effects in the environment. The cytogenetic study of blood lymphocytes from individuals that lived in the area that endured the sprayings showed the absence of chromosomal aberrations two years after the last spraying in Ecuadorian soil [13]. Also, since glyphosate has been known to cause oxidative stress in microorganisms, plant and animal species [23-29], the study analyzed three gene polymorphisms (GSTP1 Ile105Val, GPX-1 Pro198Leu, and XRCC1 Arg399Gln) that have been previously associated to the alteration of antioxidant activity, DNA detoxicating processes, and protective functions [3033]. The GSTP1 gene encodes for glutathione S-transferase pi, an enzyme that is involved in the protection against exogenous and endogenous oxidative damage [34]. As a member of the gluthatione-S-transferase superfamily of enzymes, GSTpi participates in the conjugation of xenobiotics, such as herbicides, insecticides, and other environmental carcinogens, to form glutathione and facilitate their excretion $[35,36]$. Specifically, the GSTP1 Ile105Val polymorphism has been associated to higher levels of DNA damage in pesticide-exposed populations [37]. In the Ecuadorian population studied, the prevalence of the GSTP1 $\mathrm{Val} / \mathrm{Val}$ genotype associated with enzyme dysfunction was observed in the exposed individuals. On the other hand, the GPX-1 gene encodes for one of the most important detoxifying enzymes: gluthatione peroxidase. This enzyme protects mammalian cells, especially human erythrocytes, against oxidative damage [38]. Studies have shown that the loss of gluthatione peroxidase activity can generate tissue damage [39] and offer more sensitivity towards toxic 
xenobiotics, such as paraquat and adriamycin [38]. Although the GPX-1 Pro198Leu polymorphism has been exhaustively studied in relation to cancer, the study in Ecuador identified the prevalence of the Leu allele of the GPX-1 gene in glyphosate-exposed individuals that suggests a higher risk of DNA damage and increased sensitivity to herbicides. The third gene that was part of the study, XRCC1, is involved in the mechanisms of DNA single-strand breaks (SSBs) and base-excision repair (BER) that could modify the individual susceptibility to the genotoxic effect of xenobiotics [40, 41]. Although other studied populations have found an association between $X R C C 1$ gene genotypes and an increased risk of DNA damage due to pesticide exposure, similar results were not found for the Ecuadorian population studied [42]. Aside from the cytogenetic and molecular analysis carried out, the social conditions of the population were surveyed and psychological assessment was offered to all the individuals. The results of these two activities suggested the negative effect of the fumigations on the individuals' mental health, social conditions, and quality of life [13].

A previous study took place two years before the aforementioned study at the Ecuadorian border. It involved individuals living within $200 \mathrm{~m}$ to $3 \mathrm{Km}$ from the areas under continuous and sporadic spraying [14, 43]. The comet assay technique, described by Singh et al., 1988 [44], was carried out on blood samples from exposed individuals and corresponding controls to show the occurrence of DNA fragmentation. DNA damage was classified into five categories and the mean of DNA migration was recorded. The results showed that the exposed group displayed significantly higher mean DNA migration than the control group. Similarly, there was a higher degree of DNA damage in the exposed group in comparison to the control group. These results suggest a negative effect of the glyphosate formulation since none of the studied individuals had been previously or simultaneously exposed to other toxic compounds, such as pesticides or tobacco [6]. The northern strip on the Ecuadorian border has not gone unnoticed in the controversy regarding aerial sprayings and their consequences. Nevertheless, the genotoxic and overall toxic potential of glyphosate remains under study and in vitro findings [4549] have reached a variety of results [29]. The two studies carried out in the Ecuadorian border suggest a significant and immediate risk arising from the use of this chemical and prompt to continue its investigation.

\section{Other Pesticide Genotoxicity Studies}

Despite the known risks of the use of some pesticides due to their potential health consequences [25], many of those catalogued as extremely toxic continue being used in certain agricultural zones and flower plantations in Ecuador [9]. Pesticides are widely used all over the world in agriculture to protect crops and in public health to control diseases $[50,51]$. The risk of developing malignancies such as cancer in occupationally exposed populations is of great concern and has drawn attention to workers in various activities, from the manufacturing workers to the pesticide applicators [52]. Studies available in scientific literature have focused their methodology on cytogenetic endpoints to evaluate the potential genotoxicity of pesticides, including chromosomal aberrations (CAs), micronuclei (MN), and sister chromatid exchanges (SCEs) $[52,53]$. The analysis of chromosomal aberrations such as breaks, dicentric chromosomes, and rings was part of the methodology used in a leading pesticide exposure study carried out in flower plantation workers in Quito. These workers were exposed to 27 different pesticides, some of which have been previously labeled as highly toxic [9]. Also, the level of erythrocyte acetylcholinesterase was measures in every individual as a marker to evaluate the exposure to organophosphate pesticides [54]. The study found an overall CA percentage of $20.59 \%$ in the exposed group and $2.73 \%$ of CA in the control group. Additionally, the exposed group showed a higher proportion of chromatid-type aberrations and numeric alterations. This does not only reflect genomic instability but also comprises outstanding evidence of damage supported by the abnormal low levels of acetylcholinesterase seen in the exposed group [55].

Pesticide genotoxicity was also studied in individuals working as pesticide applicators in the zone of Cayambe, northeast from Quito. The workers were exposed to 46 pesticides of different degrees of toxicity and at different concentrations and mixtures during work at the plantation [56]. The methodology involved chromosomal aberration test matched with alkaline comet assay [55]. Additionally, the samples were analyzed at a molecular level focusing on the CYP1A1 gene, a gene that has been extensively studied in relation to occupationally exposure to pesticides [56]. Because the gene is involved in the human xenobiotic metabolism, its alteration presumably increases the risk of developing lung, colorectal, prostate, and breast cancer [5761]. In accordance to the first study carried out in workers from Quito, the results of the CA analysis in this study showed the significantly high presence of chromosomal damage in the exposed group as compared to the control group. Furthermore, the comet assay test offered results that supported the CA analysis by showing that the DNA migration of the exposed group was certainly higher than that of the control group. On the other hand, the study presented no correlation between the cytogenetic findings and genotyping of the CYP1A1 MspI and Ile/Val gene polymorphisms. Though CA and comet assay showed interesting results, the gene was not linked to pesticide exposure in the studied population, as opposed to other populations $[62,63]$.

As an important element of the agricultural production, pesticides have become a necessary tool for crop management in developing countries $[64,65]$. Nonetheless, the lack of adequate legislation and enforcement of existing pesticide laws and regulations places agricultural workers, their families, and nearby populations in great risk of developing cancer and other diseases [66]. Our study shows evidence of genotoxic damage in individuals occupationally exposed to pesticides in Ecuador. These are results that demand the establishment of effective exposure biomarkers that could be used for biomonitoring the threatened workers in order to prevent the future development of illness [5]. 


\section{Hydrocarbons Genotoxicity Studies}

The Ecuadorian Amazon is one of the ecologically richest regions in the world and it is also sparsely populated. The oil extraction activity in Ecuador began in 1972, it became economically fundamental immediately and continues to be the principal source of national income [67]. Unfortunately, along the process, millions of gallons of oil and toxic residues have been discarded directly onto the environment causing health and environmental issues [68-71]. Indeed, more than 30 billion gallons of toxic wastes and crude oil had been discharged into the land and waterways of the Ecuadorian Amazon up until 1993 [72]. Crude oil is a complex mixture of many chemical compounds. It contains a variety of hydrocarbons of diverse toxicological power such as benzene, toluene, xylene and polynuclear aromatic hydrocarbons [73]. High concentrations of benzene can cause neurotoxin symptoms that cause injuries to the bone marrow and, less frequently, pancytopenia [74]. Similarly, benzene is known to cause leukemia and the development of hematological tumors [75]. The exposure to carcinogen compounds used in the oil industry increases the development of cancer in men, women, and children. In men, an increase of lung, esophagus, rectum, skin, and kidney cancer has been noticed. In women, researchers have seen an increase of cervical, lymphatic ganglion, and bladder cancer. In children, an increase of hematopoietic cancer has been shown among other types of cancer [75-86]. Studies carried out in the Ecuadorian Amazon Basin were found to be compatible with international studies. A relationship between cancer incidence and living in proximity to oil fields has been established [87]. An initial study was carried out in the province of Orellana including 23 women living not more than $10 \mathrm{Km}$ away from a crude oil extraction zone, with the corresponding control group. In order to assess genotoxicity, the comet assay test was used to measure DNA damage by classifying the nucleus morphology into five categories. The sampling zones closest to the extraction wells showed a greater evidence of DNA damage than those that are farther away which suggests a distance-damage relationship. This relationship is also supported by the increased occurrence of type A nuclei (no damage) as the distance from the wells increases [88]. Another study was carried out with a significantly bigger sample size from the nearby zone of San Carlos and matching controls from both San Carlos and the country's capital Quito. Comet assay showed that the affected group has a high occurrence of type B nuclei fragmentation, as opposed to the prevalence of type A cells in the control groups from San Carlos and Quito. Additionally, the analysis of chromosomal aberrations showed that $20 \%$ of the exposed individuals presented chromosomal breaks and gaps while only $2 \%$ of the control individuals had such aberrations [88]. At a molecular level, we incorporated the analysis of the polymorphisms of the genes CYP1A1 (MspI and Ile/Val) and MSH2 (gIVS12-6T >C), both related to the development of cancer $[58,59,89,90]$. The results of this last part of the study showed that the CYP1A1 gene polymorphisms were not related to either group, as it has been reported previously in the Caucasian population [58].
However, the study showed a significant difference of the $\mathrm{MSH} 2$ gene polymorphism between groups which suggests a higher susceptibility to DNA damage in the exposed group [7]. The chemical complexity of petroleum causes that, once a spill occurs, the constituents disseminate into different extents between the oil phase and the air, soil and water phases of the environment. Physical, chemical, and biological processes age the spilled product resulting in additional changes in composition and complexity [91]. Taking in to consideration the toxicity of these fractions, the risk at petroleum extraction sites is an issue that must be addressed by making informed decisions. By comparing the affected group with the control individuals living in the same town though far from the extraction sites, the study has been able to evidence of the genotoxicity in the exposed population living in nearby petroleum extraction wells. This suggests that the contaminating material resulting from this activity has created an altered environment that exposes the population to chemical fractions considered as dangerous and may also cause genotoxic effects.

\section{Radiation Genotoxicity Studies}

Environmental mutagens can be broadly classified as radiation and chemicals [92]. Ionizing radiation is capable of extracting electrons of the radiated material due to its high energy. This is only a start point for other ionizing reactions that produce more unstable molecules that eventually cause mutations in DNA [93].

Ever since X-rays were shown to induce mutation in Drosophila over 70 years ago, the established idea has been that the genotoxic effects of ionizing radiation, such as mutations and carcinogenesis, are caused by the direct damage of the cell nucleus [94, 95]. Diagnostic radiology is a field of physical medicine that uses X-rays in order to obtain functional and anatomical information on the human body [96]. Because of the benefits of this diagnostic tool that allows real-time visualization, it is frequently used by the medical professionals [96].

Ionizing radiation is capable of acting on the living cell causing several effects that result from the excitation of atoms and molecules that ultimately cause structural changes. At a molecular level, DNA is possibly affected by water ionization that forms free radicals and promotes the oxidation of several compounds and hydrogen oxide [97]. Even small doses of this radiation could cause great damage because a simple electron excitation can break up to 20 hydrogen bonds [98-100]. The damage resulting from radiation exposure can be seen in the form of chromosomal aberrations in the cell nucleus that are associated with an elevating risk of developing cancer [101]. A first study focused on 10 individuals exposed to radiation in the workplace. They were exposed to $1.84 \mathrm{mSv} /$ year and received a follow-up cytogenetic study after a year from the first blood sampling. The chromosomal aberration results found by the cytogenetic analysis showed interesting results in both instances [102]. First, they showed that complex chromosome alterations, such as rings and dicentrics, are 
present in low percentages contrary to the occurrence of simple alterations (gaps, breaks, and acentrics). This is due to the fact that $72 \mathrm{~h}$ cultures were used. By then, cells have gone through a second and third mitotic divisions. Therefore, primary alterations have been kept and turned into secondary aberrations in the growing generations; meanwhile, early cells with complex alterations have already died $[103,104]$. Two individuals exposed to higher doses of radiation (4.54 and $1.07 \mathrm{mSv}$, resp.) did show complex alterations in the second sampling. This is an unusual finding likely to be caused by the individuals' sporadic exposure to higher amounts of radiation. A significant increase of chromosomal aberrations was observed by comparing CA during the first and the second sampling. Out of these, there was a higher number of lesions at the chromatid level (mostly gaps) possibly due to the proper action of DNA repair mechanisms at low doses of exposure over long periods of time $[102,105]$. Other studies have also found an increase of CA in individuals exposed to similar doses of radiation, but have not addressed the importance of periodic biomonitoring [106]. Though numerical aberrations were not the focus of the study, the exposed individuals showed an increased frequency of hyperploidies and hypoploidies possibly due to the imbalance in the cell cycle caused by the exposure to toxic agents [107]. This data evidences the importance of periodic control of the occupational exposure and of monitoring the dosage-time levels of exposure at the workplace [102].

A second study focused on telomeric associations in individuals exposed both to X-rays and smoke in order to determine the existence of these associations as chromosomal markers of exposure to these carcinogenic agents. The phenomenon of telomeric association is an intermediate step in the progression towards chromosomal instability that also comprises a risk of developing cancer [108, 109]. Cytogenetic monitoring is currently accepted as an evaluation tool for exposed populations at risk as it has been used in studies regarding ionizing radiation [5]. Cytogenetic analysis of cigarette smokers has shown the occurrence of chromosomal aberrations in populations from Colombia and India [110, 111]. In this study, mitotic indices determined in all groups (smokers exposed to radiation, nonsmokers exposed to radiation, smokers unexposed, and unexposed nonsmokers) showed no correlations between the exposure to both carcinogens and the mitotic indices and cell proliferation. Nonetheless, the three different exposed groups showed high frequencies of telomeric associations [112]. These results were particularly surprising for cigarette smokers since no cytogenetic biomarker of exposure for cigarette had been demonstrated to be consistent so far. Also, the group of smokers unexposed to radiation showed higher frequencies of TA than the nonsmoking X-ray-exposed group, a result that was possibly due to the many carcinogens present in cigarette smoke $[110,111,113]$. Though it has been reported that both agents have a synergistic effect [113], our study did not find such a tendency. However, the group exposed to both agents did show the highest frequency of telomeric associations. The study suggested that telomeric associations can assess the genomic instability phenomena in populations exposed to mutagens. Although, telomere length has been reported as a biomarker for age, stress and cancer, telomere biology and the molecular pathways that protect telomeres continue to be studied in order to determining the outcome of radiation exposure [114].

In another study, the inclusion of gaps as chromosomal aberration was investigated. Gaps are defined as the unstained regions of a chromosome that contain zones of lesser width than that of a chromatid $[115,116]$. A gap is observed as an empty space because the DNA thread is so thin that it becomes practically invisible to the usual technique [113]. Since genotoxic agents such as ionizing radiation are capable of inducing chromosomal uncoiling events and affecting DNA condensation, gaps can certainly be the product of exposure to genotoxic agents [117]. Nonetheless, some authors had considered gaps to be structures that lack biological significance [118]. The study involved individuals exposed to X-rays and the unexposed control group. The findings of the CA analysis and comet assay were compared, including and excluding gaps. These two complementary techniques do not detect the same kind of lesions. On one hand, chromosomal aberrations are originated from doublestrand breaks; on the other hand, comet assay can detect single-strand breaks, double-strand breaks, and alkali labile sites (when using the alkaline version) [119] and has proven to be a useful way of assessing X-ray damage to lymphocytes [120]. The correlation between the two methods including gaps as CA was positive. Gaps measured damage in the DNA since there was a stronger correlation between the results of both applied techniques when gaps were included as a CA. Although there is an increasing interest in studying the more complex chromosomal aberrations such as dicentrics and translocations, current studies still include gaps as part of the genotoxicity studies [121-124]. These findings suggested a revision of the biological importance of gaps in population occupational biomonitoring [124]. Furthermore, another study involved a group of radiologists and technicians exposed to X-rays at the workplace, excluding those with family and personal history of cancer and smoke exposure. The mean dose of ionizing radiation for the affected group was $0.99 \mathrm{mSv}$ and the chromosomal aberrations observed involved gaps, breaks, dicentric, rings, and double minutes. The cytogenetic analysis showed that CAs were present in $50 \%$ of the individuals in the exposed group and in $2 \%$ of the control individuals. However, these results were not statistically significant. On the other hand, the comet assay did show a highly significant difference of migration in the exposed group as compared to the control group, possibly because the comet assay shows a wider set of damage consequences $[93,125]$. Similarl to a study carried out in Iran that found no specific relation with the characteristics of the occupational setting and the duration of exposure [126], this study found no correlation between the results of both tests and the duration and dose of exposure due to a lack of significant variation between individual doses. Such results may also support the idea of hormesis taking place as a way of adapting to the workplace after several years, though the idea remains to be controversial [127]. Even though there were no significant results regarding CA, relative risk calculation 
showed that exposed individuals had a risk 20 times higher of showing aberrations than the control group [128]. These aberrations may lead to the alteration of cell control mechanisms such as apoptosis and tumor suppressor genes, besides the loss of genetic material due to cell death as a result of changes in division and repairing mechanisms [129-131]. Although this study did not show an association between CA and exposure time or dose level, other studies have agreed on the fact that long-term exposure to low radiation levels are the cause for higher percentages of CA $[132,133]$.

Cytogenetic findings are of great importance because they are associated with the mechanisms of carcinogenesis. The interaction with physical agents, such as ionizing radiation, produces a variety of primary lesions [134] whose prevalence can determine cancer risk [135]. Because of the importance of biomonitoring occupationally exposed populations, proper research guidelines have been established [136]. mFISH assays are currently being put in use in order to carry out a more detailed analysis of simple and complex aberrations that could model the effects of radiation on lymphocytes [107]. Nonetheless, earlier cytogenetic techniques are still held as the golden standard for biomonitoring populations. Environmental and occupational health issues are increasingly being studied because of its importance in public health. In Ecuador, going through a preliminary cytogenetic testing to evaluate the genotoxic effects of different agents is a rather voluntary decision and the toxic qualities of certain widely used chemicals, such as herbicides and pesticides, are not of common knowledge. According to the results obtained in this set of studies, adequate biomonitoring laws should be enforced. In the case of glyphosate, research has helped to consider changes regarding the targeted areas, duration of sprayings and chemical composition of herbicides. Though plantations and industries do offer protective equipment, this gear is not always used by the small farm owner. Reports on the use of highly toxic pesticides conclude that the lack of regulation of pesticide use benefits the informal distribution of these hazardous compounds, not only in flower plantations but increasingly in small farms. Lastly, occupational health risks must be studied in all professions that face any level of exposure to physical or chemical agents suspected to cause illness. Radiologists and other professionals exposed to radiation should have access to cytogenetics testing and follow-up studies that can report on any unusual results in order to prevent diseases as part of occupational health and safety laws.

\section{References}

[1] J. Bohne and T. Cathomen, "Genotoxicity in gene therapy: an account of vector integration and designer nucleases," Current Opinion in Molecular Therapeutics, vol. 10, no. 3, pp. 214-223, 2008.

[2] M. Uhl, M. J. Plewa, B. J. Majer, and S. Knasmüller, "Basic principles of genetic toxicology with an emphasis on plant bioassays," in Bioassays in Plant Cells for Improvement of Ecosystem and Human Health, J. Maluszynska and M. Plewa, Eds., pp. 11-30, Katowice, Poland, 2003.
[3] G. H. Westphalen, L. M. Menezes, D. Prá et al., "In vivo determination of genotoxicity induced by metals from orthodontic appliances using micronucleus and comet assays," Genetics and Molecular Research, vol. 7, no. 4, pp. 1259-1266, 2008.

[4] F. Henkler and A. Luch, "Adverse health effects of environmental chemical agents through non-genotoxic mechanisms," Journal of Epidemiology and Community Health, vol. 65, no. 1, pp. 1-3, 2011.

[5] T. Adamus, I. Mikulenková, L. Dobiáš, J. Havránková, and T. Pek, "Cytogenetic methods and biomonitoring of occupational exposure to genotoxic factors," Journal of Applied Biomedicine, vol. 4, no. 4, pp. 197-203, 2006.

[6] C. Paz-y-Miño, M. E. Sánchez, M. Arévalo et al., "Evaluation of DNA damage in an Ecuadorian population exposed to glyphosate," Genetics and Molecular Biology, vol. 30, no. 2, pp. 456-460, 2007.

[7] C. Paz-y-Miño, A. López-Cortés, M. Arévalo, and M. E. Sánchez, "Monitoring of DNA damage in individuals exposed to petroleum hydrocarbons in Ecuador," Annals of the New York Academy of Sciences, vol. 1140, pp. 121-128, 2008.

[8] A. Joaquín, S. Vallejo, and R. Trejos, Más que Alimentos en la Mesa: La Real Contribución de la Agricultura a la Economía del Ecuador, vol. 11, Instituto Interamericano de Cooperación para la Agricultura (IICA), Quito, Ecuador, 2005.

[9] C. Paz-y-Miño, G. Bustamante, M. E. Sáchez, and P. E. Leone, "Cytogenetic monitoring in a population occupationally exposed to pesticides in ecuador," Environmental Health Perspectives, vol. 110, no. 11, pp. 1077-1080, 2002.

[10] C. Paz-y-Miño, M. V. Dávalos, M. E. Sánchez, M. Arévalo, and P. E. Leone, "Should gaps be included in chromosomal aberration analysis?: evidence based on the comet assay," Mutation Research, vol. 516, no. 1-2, pp. 57-61, 2002.

[11] M. Stoia, S. Oancea, and D. C. Obreja, "Comparative study of genotoxic effects in workers exposed to inorganic lead and low dose irradiation using micronucleus test," Romanian Journal of Legal Medicine, vol. 17, no. 4, pp. 287-294, 2009.

[12] V. Garaj-Vrhovac and N. Kopjar, "The alkaline Comet assay as biomarker in assessment of DNA damage in medical personnel occupationally exposed to ionizing radiation," Mutagenesis, vol. 18, no. 3, pp. 265-271, 2003.

[13] C. Paz-y-Miño, M. J. Muñoz, A. Maldonado et al., "Baseline determination in social, health, and genetic areas in communities affected by glyphosate aerial spraying on the northeastern Ecuadorian border," Reviews on Environmental Health, vol. 26, no. 1, pp. 45-51, 2011.

[14] Ministerio de Relaciones Exteriores (MREE), Misión de Verificación: Impactos en el Ecuador de las Fumigaciones Realizadas en el Departamento del Putumayo dentro del Plan Colombia, Ministerio de Relaciones Exteriores del Ecuador, Quito, Ecuador, 2002.

[15] S. O. Duke and S. B. Powles, "Glyphosate: a once-in-a-century herbicide," Pest Management Science, vol. 64, no. 4, pp. 319-325, 2008.

[16] J. F. Acquavella, B. H. Alexander, J. S. Mandel, C. Gustin, B. Baker, and P. Chapman, "Glyphosate biomonitoring for farmers and their families: results from the farm family exposure study," Environmental Health Perspectives, vol. 112, no. 3, pp. 321-326, 2004.

[17] N. Benachour and G. E. Séralini, "Glyphosate formulations induce apoptosis and necrosis in human umbilical, embryonic, and placental cells," Chemical Research in Toxicology, vol. 22, no. 1, pp. 97-105, 2009. 
[18] A. Martínez, I. Reyes, and N. Reyes, "Cytotoxicity of the herbicide glyphosate in human peripheral blood mononuclear cells," Biomedica, vol. 27, no. 4, pp. 594-604, 2007.

[19] C. M. Howe, M. Berrill, B. D. Pauli, C. C. Helbing, K. Werry, and N. Veldhoen, "Toxicity of glyphosate-based pesticides to four North American frog species," Environmental Toxicology and Chemistry, vol. 23, no. 8, pp. 1928-1938, 2004.

[20] S. K. Dinehart, L. M. Smith, S. T. McMurry, T. A. Anderson, P. N. Smith, and D. A. Haukos, "Toxicity of a glufosinate- and several glyphosate-based herbicides to juvenile amphibians from the Southern High Plains, USA," Science of the Total Environment, vol. 407, no. 3, pp. 1065-1071, 2009.

[21] J. Marc, O. Mulner-Lorillon, S. Boulben, D. Hureau, G. Durand, and R. Bellé, "Pesticide roundup provokes cell division dysfunction at the level of CDK1/cyclin B activation," Chemical Research in Toxicology, vol. 15, no. 3, pp. 326-331, 2002.

[22] R. Bellé, R. Le Bouffant, J. Morales, B. Cosson, P. Cormier, and O. Mulner-Lorillon, "Sea urchin embryo, DNA-damaged cell cycle checkpoint and the mechanisms initiating cancer development," Journal de la Societe de Biologie, vol. 201, no. 3, pp. 317-327, 2007.

[23] D. M. Romero, M. C. Ríos de Molina, and Á. B. Juárez, "Oxidative stress induced by a commercial glyphosate formulation in a tolerant strain of Chlorella kessleri," Ecotoxicology and Environmental Safety, vol. 74, no. 4, pp. 741-747, 2011.

[24] N. S. El-Shenawy, "Oxidative stress responses of rats exposed to Roundup and its active ingredient glyphosate," Environmental Toxicology and Pharmacology, vol. 28, no. 3, pp. 379385, 2009.

[25] M. Mladinic, S. Berend, A. L. Vrdoljak, N. Kopjar, B. Radic, and D. Zeljezic, "Evaluation of genome damage and its relation to oxidative stress induced by glyphosate in human lymphocytes in vitro," Environmental and Molecular Mutagenesis, vol. 50, no. 9, pp. 800-807, 2009.

[26] O. V. Lushchak, O. I. Kubrak, J. M. Storey, K. B. Storey, and V. I. Lushchak, "Low toxic herbicide Roundup induces mild oxidative stress in goldfish tissues," Chemosphere, vol. 76, no. 7, pp. 932-937, 2009.

[27] K. A. Modesto and C. B. R. Martinez, "Roundup $($ causes oxidative stress in liver and inhibits acetylcholinesterase in muscle and brain of the fish Prochilodus lineatus," Chemosphere, vol. 78, no. 3, pp. 294-299, 2010.

[28] N. Ahsan, D. G. Lee, K. W. Lee et al., "Glyphosateinduced oxidative stress in rice leaves revealed by proteomic approach," Plant Physiology and Biochemistry, vol. 46, no. 12, pp. 1062-1070, 2008.

[29] L. Goldman, Childhood Pesticide Poisoning, United Nations Environment Program, Geneva, Switzerland, 2004, http:// www.who.int/ceh/publications/pestpoisoning.pdf.

[30] I. Meiers, J. H. Shanks, and D. G. Bostwick, "Glutathione Stransferase pi (GSTP1) hypermethylation in prostate cancer: review 2007," Pathology, vol. 39, no. 3, pp. 299-304, 2007.

[31] H. W. Lo, L. Stephenson, X. Cao, M. Milas, R. Pollock, and F. Ali-Osman, "Identification and functional characterization of the human Glutathione S-transferase P1 gene as a novel transcriptional target of the p53 tumor suppressor gene," Molecular Cancer Research, vol. 6, no. 5, pp. 843-850, 2008.

[32] A. M. Moyer, O. E. Salavaggione, T. Y. Wu et al., "Glutathione S-transferase P1: gene sequence variation and functional genomic studies," Cancer Research, vol. 68, no. 12, pp. 47914801, 2008.
[33] R. H. Wong, C. L. Du, J. D. Wang, C. C. Chan, J. C. J. Luo, and T. J. Cheng, "XRCC1 and CYP2E1 polymorphisms as susceptibility factors of plasma mutant $\mathrm{p} 53$ protein and antip53 antibody expression in vinyl chloride monomer-exposed polyvinyl chloride workers," Cancer Epidemiology Biomarkers and Prevention, vol. 11, no. 5, pp. 475-482, 2002.

[34] C. Jerónimo, G. Varzim, R. Henrique et al., "I105V polymorphism and promoter methylation of the GSTP1 gene in prostate adenocarcinoma," Cancer Epidemiology Biomarkers and Prevention, vol. 11, no. 5, pp. 445-450, 2002.

[35] L. Kadouri, Z. Kote-Jarai, A. Hubert et al., "GlutathioneS-transferase M1, T1 and P1 polymorphisms, and breast cancer risk, in BRCA1/2 mutation carriers," British Journal of Cancer, vol. 98, no. 12, pp. 2006-2010, 2008.

[36] C. Martínez, E. García-Martín, H. Alonso-Navarro et al., "Glutathione-S-transferase P1 polymorphism and risk for essential tremor," European Journal of Neurology, vol. 15, no. 3, pp. 234-238, 2008.

[37] Y. J. Liu, P. L. Huang, Y. F. Chang et al., "GSTP1 genetic polymorphism is associated with a higher risk of DNA damage in pesticide-exposed fruit growers," Cancer Epidemiology Biomarkers and Prevention, vol. 15, no. 4, pp. 659-666, 2006.

[38] J. M. Matés, "Effects of antioxidant enzymes in the molecular control of reactive oxygen species toxicology," Toxicology, vol. 153, no. 1-3, pp. 83-104, 2000.

[39] J. R. Arthur, "The glutathione peroxidases," Cellular and Molecular Life Sciences, vol. 57, no. 13-14, pp. 1825-1835, 2000.

[40] P. Rohr, J. da Silva, B. Erdtmann et al., "BER gene polymorphisms (OGG1 Ser326Cys and XRCC1 Arg194Trp) and modulation of DNA damage due to pesticides exposure," Environmental and Molecular Mutagenesis, vol. 52, no. 1, pp. 20-27, 2011.

[41] M. C. Stern, D. M. Umbach, C. H. Van Gils, R. M. Lunn, and J. A. Taylor, "DNA repair gene XRCC1 polymorphisms, smoking, and bladder cancer risk," Cancer Epidemiology Biomarkers and Prevention, vol. 10, no. 2, pp. 125-131, 2001.

[42] R. H. Wong, S. Y. Chang, S. W. Ho et al., "Polymorphisms in metabolic GSTP1 and DNA-repair XRCC1 genes with an increased risk of DNA damage in pesticide-exposed fruit growers," Mutation Research, vol. 654, no. 2, pp. 168-175, 2008.

[43] Acción Ecológica, Frontera: Daños Genéticos Por las Fumigaciones del Plan Colombia, Acción Ecológica, Quito, Ecuador, 2004.

[44] N. P. Singh, M. T. McCoy, R. R. Tice, and E. L. Schneider, "A simple technique for quantitation of low levels of DNA damage in individual cells," Experimental Cell Research, vol. 175, no. 1, pp. 184-191, 1988.

[45] D. D. Evans and M. J. Batty, "Effects of high dietary

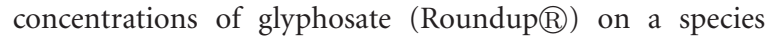
of bird, marsupial and rodent indigenous to Australia," Environmental Toxicology and Chemistry, vol. 5, no. 4, pp. 399-401, 1986.

[46] G. M. Williams, R. Kroes, and I. C. Munro, "Safety evaluation and risk assessment of the herbicide Roundup and its active ingredient, glyphosate, for humans," Regulatory Toxicology and Pharmacology, vol. 31, no. 2, pp. 117-165, 2000.

[47] D. A. Goldstein, J. F. Acquavella, R. M. Mannion, and D. R. Farmer, "An analysis of glyphosate data from the California Environmental Protection Agency pesticide illness surveillance program," Journal of Toxicology, vol. 40, no. 7, pp. 885$892,2002$. 
[48] M. H. Bernal, K. R. Solomon, and G. Carrasquilla, "Toxicity of formulated glyphosate (Glyphos) and cosmo-flux to larval and juvenile colombian frogs 2 . field and laboratory microcosm acute toxicity," Journal of Toxicology and Environmental Health-Part A, vol. 72, no. 15-16, pp. 966-973, 2009.

[49] K. R. Solomon, A. Anadón, G. Carrasquilla, A. L. Cerdeira, J. Marshall, and L.-H. Sanin, "Coca and poppy eradication in Colombia: environmental and human health assessment of aerially applied glyphosate," Reviews of Environmental Contamination and Toxicology, vol. 190, pp. 43-125, 2007.

[50] N. Sailaja, M. Chandrasekhar, P. V. Rekhadevi et al., "Genotoxic evaluation of workers employed in pesticide production," Mutation Research, vol. 609, no. 1, pp. 74-80, 2006.

[51] S. Bull, K. Fletcher, A. R. Boobis, and J. M. Battershill, "Evidence for genotoxicity of pesticides in pesticide applicators: a review," Mutagenesis, vol. 21, no. 2, pp. 93-103, 2006.

[52] C. Bolognesi, "Genotoxicity of pesticides: a review of human biomonitoring studies," Mutation Research, vol. 543, no. 3, pp. 251-272, 2003.

[53] P. Grover, K. Danadevi, M. Mahboob, R. Rozati, B. S. Banu, and M. F. Rahman, "Evaluation of genetic damage in workers employed in pesticide production utilizing the Comet assay," Mutagenesis, vol. 18, no. 2, pp. 201-205, 2003.

[54] V. Ng, D. Koh, A. Wee, and S. E. Chia, "Salivary acetylcholinesterase as a biomarker for organophosphate exposure," Occupational Medicine, vol. 59, no. 2, pp. 120-122, 2009.

[55] C. Paz-y-Miño, M. Arévalo, M. E. Sanchez, and P. E. Leone, "Chromosome and DNA damage analysis in individuals occupationally exposed to pesticides with relation to genetic polymorphism for CYP 1Algene in Ecuador," Mutation Research, vol. 562, no. 1-2, pp. 77-89, 2004.

[56] V. Kumar, C. S. Yadav, S. Singh et al., "CYP 1A1 polymorphism and organochlorine pesticides levels in the etiology of prostate cancer," Chemosphere, vol. 81, no. 4, pp. 464-468, 2010.

[57] A. M. Tsatsakis, A. Zafiropoulos, M. N. Tzatzarakis, G. N. Tzanakakis, and A. Kafatos, "Relation of PON1 and CYP1A1 genetic polymorphisms to clinical findings in a crosssectional study of a Greek rural population professionally exposed to pesticides," Toxicology Letters, vol. 186, no. 1, pp. 66-72, 2009.

[58] C. San Jose, A. Cabanillas, J. Benitez, J. A. Carrillo, M. Jimenez, and G. Gervasini, "CYP1A1 gene polymorphisms increase lung cancer risk in a high-incidence region of Spain: a case control study," BMC Cancer, vol. 10, article 463, 2010.

[59] E. Taioli, L. Gaspari, S. Benhamou et al., "Polymorphisms in CYP1A1, GSTM1, GSTT1 and lung cancer below the age of 45 years," International Journal of Epidemiology, vol. 32, no. 1, pp. 60-63, 2003.

[60] J. Little, L. Sharp, L. F. Masson et al., "Colorectal cancer and genetic polymorphisms of CYP1A1, GSTM1 and GSTT1: a case-control study in the Grampian region of Scotland," International Journal of Cancer, vol. 119, no. 9, pp. 21552164, 2006.

[61] T. N. Sergentanis and K. P. Economopoulos, "Four polymorphisms in cytochrome P450 1A1 (CYP1A1) gene and breast cancer risk: a meta-analysis," Breast Cancer Research and Treatment, vol. 122, no. 2, pp. 459-469, 2010.

[62] V. M. Basham, P. D. P. Pharoah, C. S. Healey et al., "Polymorphisms in CYP1A1 and smoking: no association with breast cancer risk," Carcinogenesis, vol. 22, no. 11, pp. 1797-1800, 2001.
[63] K. Kvitko, J. C. B. Nunes, T. A. Weimer, F. M. Salzano, and M. H. Hutz, "Cytochrome P4501A1 polymorphisms in South American Indians," Human Biology, vol. 72, no. 6, pp. 10391043, 2000.

[64] A. V. Ngowi, Health Impact of Exposure to Pesticides in Agriculture in Tanzania, University of Tampere, Tampere, Finland, 2002.

[65] R. Naravaneni and K. Jamil, "Determination of AChE levels and genotoxic effects in farmers occupationally exposed to pesticides," Human and Experimental Toxicology, vol. 26, no. 9, pp. 723-731, 2007.

[66] IARC, Evaluation of Carcinogenic Risks to Humans: Occupational Exposures in Insecticide Application and Some Pesticides, vol. 53, The International Agency for Research on Cancer, Lyon, France, 1991, http://monographs.iarc.fr/ENG/Monographs/vol53/mono53.pdf.

[67] Banco Central del Ecuador (BCE), Cifras Económicas del Ecuador Abril 2009, Banco Central del Ecuador, Quito, Ecuador, 2009, http://www.bce.fin.ec/documentos/Estadisticas/SectorReal/Previsiones/IndCoyuntura/CifrasEconomicas/cie200904.pdf.

[68] P. R. Epstein and J. Selber, A Life Cycle Analysis of Its Health and Environmental Impacts, The Center for Health and the Global Environment, Boston, Mass, USA, 2002, http://chge.med.harvard.edu/publications/documents/oilfullreport.pdf.

[69] J. Kimmerling, Amazon Crude, Brickfron Graphics, New York, NY, USA, 1993.

[70] M. Neri, D. Ugolini, S. Bonassi et al., "Children's exposure to environmental pollutants and biomarkers of genetic damage: II. Results of a comprehensive literature search and metaanalysis," Mutation Research, vol. 612, no. 1, pp. 14-39, 2006.

[71] K. L. Platt, S. Aderhold, K. Kulpe, and M. Fickler, "Unexpected DNA damage caused by polycyclic aromatic hydrocarbons under standard laboratory conditions," Mutation Research, vol. 650, no. 2, pp. 96-103, 2008.

[72] C. Jochnick, R. Normand, and S. Zaidi, "Rights violations in the Ecuadorian Amazon: the human consequences of oil development," Health \& Human Rights, vol. 1, no. 1, pp. 82100, 1994.

[73] IARC, Evaluation of the Carcinogenic Risk of Chemicals to Man: Occupational Exposures to Petroleum Refining; Crude Oil and Major Petroleum Fuels, vol. 45, The International Agency for Research on Cancer, Lyon , France, 1989, http:// monographs.iarc.fr/ENG/Monographs/vol45/mono45.pdf.

[74] I. Rahman, K. Narasimhan, S. Aziz, and W. Owens, "Gasoline ingestion: a rare cause of pancytopenia," American Journal of the Medical Sciences, vol. 338, no. 5, pp. 433-434, 2009.

[75] R. B. Hayes, Y. Songnian, M. Dosemeci, and M. Linet, "Benzene and lymphohematopoietic malignancies in humans," American Journal of Industrial Medicine, vol. 40, no. 2, pp. 117-126, 2001.

[76] T. A. McDonald, Public Health Goal for Benzene in Drinking Water, Office of Environmental Health Hazard Assessment, Sacramento, Calif, USA, 2001, http://oehha.ca.gov/water/ phg/pdf/BenzeneFinPHG.pdf.

[77] W. J. Blot, L. A. Brinton, J. F. Fraumeni, and B. J. Stone, "Cancer mortality in U.S. counties with petroleum industries," Science, vol. 198, no. 4312, pp. 51-53, 1977.

[78] R. G. Olin, A. Ahlbom, and I. Lindberg-Navier, "Occupational factors associated with astrocytomas: a case-control study," American Journal of Industrial Medicine, vol. 11, no. 6, pp. 615-625, 1987. 
[79] R. A. Lyons, S. P. Monaghan, M. Heaven, B. N. C. Littlepage, T. J. Vincent, and G. J. Draper, "Incidence of leukaemia and lymphoma in young people in the vicinity of the petrochemical plant at Baglan Bay, South Wales, 1974 to 1991," Occupational and Environmental Medicine, vol. 52, no. 4, pp. 225-228, 1995.

[80] J. Kaldor, J. A. Harris, and E. Glazer, "Statistical association between cancer incidence and major-cause mortality, and estimated residential exposure to air emissions from petroleum and chemical plants," Environmental Health Perspectives, vol. 54, pp. 319-332, 1983.

[81] M. Gérin, J. Siemiatycki, M. Désy, and D. Krewski, "Associations between several sites of cancer and occupational exposure to benzene, toluene, xylene, and styrene: results of a case-control study in Montreal," American Journal of Industrial Medicine, vol. 34, no. 2, pp. 144-156, 1998.

[82] J. D. Everall and P. M. Dowd, "Influence of environmental factors excluding ultra violet radiation on the incidence of skin cancer," Bulletin du Cancer, vol. 65, no. 3, pp. 241-247, 1978.

[83] P. Boffetta, N. Jourenkova, and P. Gustavsson, "Cancer risk from occupational and environmental exposure to polycyclic aromatic hydrocarbons," Cancer Causes and Control, vol. 8, no. 3, pp. 444-472, 1997.

[84] M. S. Gottlieb, C. L. Shear, and D. B. Seale, "Lung cancer mortality and residential proximity to industry," Environmental Health Perspectives, vol. 45, pp. 157-164, 1982.

[85] C. Y. Yang, M. F. Cheng, J. F. Chiu, and S. S. Tsai, "Female lung cancer and petrochemical air pollution in Taiwan," Archives of Environmental Health, vol. 54, no. 3, pp. 180-185, 1999.

[86] B. J. Pan, Y. J. Hong, G. C. Chang, M. T. Wang, F. F. Cinkotai, and Y. C. Ko, "Excess cancer mortality among children and adolescents in residential districts polluted by petrochemical manufacturing plants in Taiwan," Journal of Toxicology and Environmental Health, vol. 43, no. 1, pp. 117-129, 1994.

[87] A. K. Hurtig and M. San Sebastián, "Geographical differences in cancer incidence in the Amazon basin of Ecuador in relation to residence near oil fields," International Journal of Epidemiology, vol. 31, no. 5, pp. 1021-1027, 2002.

[88] C. Paz-y-Miño, B. Castro, A. López-Cortés et al., "Impacto genético en comunidades amazónicas del Ecuador localizadas en zonas petroleras," Revista Ecuatoriana de Medicina y Ciencias Biológicas, vol. 1, no. 1-2, pp. 7-19, 2010.

[89] G. Thodi, F. Fostira, R. Sandaltzopoulos et al., "Screening of the DNA mismatch repair genes MLH1, MSH2 and MSH6 in a Greek cohort of Lynch syndrome suspected families," BMC Cancer, vol. 10, article 544, 2010.

[90] D. A. Lawes, T. Pearson, S. SenGupta, and P. B. Boulos, “The role of MLH1, MSH2 and MSH6 in the development of multiple colorectal cancers," British Journal of Cancer, vol. 93, no. 4, pp. 472-477, 2005.

[91] Environment Agency, Principles for Evaluating the Human Health Risks from Petroleum Hydrocarbons in Soils: A Consultation Paper, Environment Agency, Bristol, UK, 2003, http://www.environment-agency.gov.uk/static/documents/ Research/petroleum_hydrocarbons1.pdf.

[92] I. Kovalchuk, O. Kovalchuk, and B. Hohn, "Biomonitoring the genotoxicity of environmental factors with transgenic plants," Trends in Plant Science, vol. 6, no. 7, pp. 306-310, 2001.

[93] C. Paz-y-Miño, A. Creus, O. Cabré, and P. E. Leone, Genética, Toxicología y Carcinogenesis, PUCE, Quito, Ecuador, 2002.
[94] T. K. Hei, R. Persaud, H. Zhou, and M. Suzuki, "Genotoxicity in the eyes of bystander cells," Mutation Research, vol. 568, no. 1, pp. 111-120, 2004.

[95] A. V. Carrano, "Chromosome aberrations and radiationinduced cell death. I. Transmission and survival parameters of aberrations," Mutation Research, vol. 17, no. 3, pp. 341353, 1973.

[96] E. De Souza and J. P. D. M. Soares, "Occupational and technichal correlations of interventional radiology," Jornal Vascular Brasileiro, vol. 7, no. 4, pp. 341-350, 2008.

[97] J. A. V. Butler, "Effects of ultra-violet light on nucleic acid and nucleoproteins and other biological systems," Experientia, vol. 11, no. 8, pp. 289-293, 1955.

[98] D. R. Boreham, "Cellular defense mechanisms against the biological effects of ionizing radiation," in Proceedings of the 10th International Congress of International Radiation Protection Association (IRPA '00), Hiroshima, Japan, May 2000, http://w3.tue.nl/fileadmin/sbd/Documenten/IRPA_refresher_courses/Cellular_Defense_Mechanisms_Against_the_ Biological_Effects_of_Ionizing_Radiation.pdf.

[99] J. Chung, H. Ward, K. Teschke, P. A. Ratner, and Y. Chow, A Retrospective Cohort Study of Cancer Risks among Nurses in British Columbia: Potential Exposure to Ionizing Radiation Report, British Columbia: Research Secretariat of the Workers' Compensation Board of British Columbia, 2005, http://www.cher.ubc.ca/PDFs/Ionizing_Radiation_2005.pdf.

[100] G. Obe, P. Pfeiffer, J. R. K. Savage et al., "Chromosomal aberrations: formation, identification and distribution," Mutation Research, vol. 504, no. 1-2, pp. 17-36, 2002.

[101] V. Garaj-Vrhovac and D. Zeljezic, "Comet assay in the assessment of the human genome damage induced by $\gamma$ radiation in vitro," Radiology and Oncology, vol. 38, no. 1, pp. 43-47, 2004.

[102] C. Paz-y-Mino, P. E. Leone, M. Chavez et al., "Follow up study of chromosome aberrations in lymphocytes in hospital workers occupationally exposed to low levels of ionizing radiation," Mutation Research, vol. 335, no. 3, pp. 245-251, 1995.

[103] A. V. Carrano, "Chromosome aberrations and radiationinduced cell death. II. Predicted and observed cell survival," Mutation Research, vol. 17, no. 3, pp. 355-366, 1973.

[104] A. P. Krishnaja and N. K. Sharma, "Transmission of $\gamma$ ray-induced unstable chromosomal aberrations through successive mitotic divisions in human lymphocytes in vitro," Mutagenesis, vol. 19, no. 4, pp. 299-305, 2004.

[105] P. K. Gadhia, M. Gadhia, S. Georje, K. R. Vinod, and M. Pithawala, "Induction of chromosomal aberrations in mitotic chromosomes of fish Boleophthalmus dussumieri after exposure in vivo to antineoplastics Bleomycin, Mitomycin-C and Doxorubicin," Indian Journal of Science and Technology, vol. 1, no. 1, pp. 1-6, 2008.

[106] R. S. Cardoso, S. Takahashi-Hyodo, P. Peitl Jr., T. GhilardiNeto, and E. T. Sakamoto-Hojo, "Evaluation of chromosomal aberrations, micronuclei, and sister chromatid exchanges in hospital workers chronically exposed to ionizing radiation," Teratogenesis Carcinogenesis and Mutagenesis, vol. 21, no. 6, pp. 431-439, 2001.

[107] L. Hlatky, R. K. Sachs, M. Vazquez, and M. N. Cornforth, "Radiation-induced chromosome aberrations: insights gained from biophysical modeling," BioEssays, vol. 24, no. 8, pp. 714-723, 2002.

[108] R. Gertler, R. Rosenberg, D. Stricker et al., “Telomere length and human telomerase reverse transcriptase expression as 
markers for progression and prognosis of colorectal carcinoma," Journal of Clinical Oncology, vol. 22, no. 10, pp. 18071814, 2004.

[109] K. I. Nakamura, E. Furugori, Y. Esaki et al., "Correlation of telomere lengths in normal and cancers tissue in the large bowel," Cancer Letters, vol. 158, no. 2, pp. 179-184, 2000.

[110] V. Balachandar, B. L. Kumar, K. Suresh, and K. Sasikala, "Evaluation of chromosome aberrations in subjects exposed to environmental tobacco smoke in Tamilnadu, India," Bulletin of Environmental Contamination and Toxicology, vol. 81, no. 3, pp. 270-276, 2008.

[111] M. S. Sierra-Torres, Y. Y. Arboleda-Moreno, L. S. Hoyos, and C. H. Sierra-Torres, "Chromosome aberrations among cigarette smokers in Colombia," Mutation Research, vol. 562, no. 1-2, pp. 67-75, 2004.

[112] C. Paz-y-Miño, J. C. Pérez, V. Dávalos, M. E. Sánchez, and P. E. Leone, "Telomeric associations in cigarette smokers exposed to low levels of X-rays," Mutation Research, vol. 490, no. 1, pp. 77-80, 2001.

[113] K. B. S. Kumar, R. Ankathil, and K. S. Devi, "Chromosomal aberrations induced by methyl parathion in human peripheral lymphocytes of alcoholics and smokers," Human and Experimental Toxicology, vol. 12, no. 4, pp. 285-288, 1993.

[114] S. D. Bouffler, M. A. Blasco, R. Cox, and P. J. Smith, "Telomeric sequences, radiation sensitivity and genomic instability," International Journal of Radiation Biology, vol. 77, no. 10, pp. 995-1005, 2001.

[115] Y. Saitoh, Y. Harata, F. Mizuhashi, M. Nakajima, and N. Miwa, "Biological safety of neutral-pH hydrogen-enriched electrolyzed water upon mutagenicity, genotoxicity and subchronic oral toxicity," Toxicology and Industrial Health, vol. 26, no. 4, pp. 203-216, 2010.

[116] U. Von Recklinghausen, C. Johannes, L. Riedel, and G. Obe, "Aberration patterns and cell cycle progression following exposure of lymphocytes to the alkylating agent Trenimon," Chromosome Alterations, pp. 315-324, 2007.

[117] L. C. Sánchez-Peña, B. E. Reyes, L. López-Carrillo et al., "Organophosphorous pesticide exposure alters sperm chromatin structure in Mexican agricultural workers," Toxicology and Applied Pharmacology, vol. 196, no. 1, pp. 108-113, 2004.

[118] J. Friedman, F. Shabtai, L. S. Levy, and M. Djaldetti, "Chromium chloride induces chromosomal aberrations in human lymphocytes via indirect action," Mutation Research, vol. 191, no. 3-4, pp. 207-210, 1987.

[119] P. L. Olive and J. P. Banáth, "The comet assay: a method to measure DNA damage in individual cells," Nature Protocols, vol. 1, no. 1, pp. 23-29, 2006.

[120] D. Milković, V. Garaj-Vrhovac, M. Ranogajec-Komor et al., "Primary DNA damage assessed with the comet assay and comparison to the absorbed dose of diagnostic X-rays in children," International Journal of Toxicology, vol. 28, no. 5, pp. 405-416, 2009.

[121] L. Jiunn-Wang, H. Ching-I, M. Isao, and C. Yng-Tay, "Chloroacetaldehyde indices chromosome aberrations and micronucleus formation but not 2-chloroethanol," Journal of Health Science, vol. 57, no. 3, pp. 300-303, 2011.

[122] L. C. Silva-Pereira, P. C. S. Cardoso, D. S. Leite et al., "Cytotoxicity and genotoxicity of low doses of mercury chloride and methylmercury chloride on human lymphocytes in vitro," Brazilian Journal of Medical and Biological Research, vol. 38, no. 6, pp. 901-907, 2005.
[123] T. Kyoya, Y. Obara, and A. Nakata, "Chromosomal aberrations in Japanese grass voles in and around an illegal dumpsite at the Aomori-Iwate prefectural boundary," Zoological Science, vol. 25, no. 3, pp. 307-312, 2008.

[124] K. Guleria and V. Sambyal, "Spectrum of chromosomal aberrations in peripheral blood lymphocytes of gastrointestinal tract (GIT) and breast cancer patients," International Journal of Human Genetics, vol. 10, no. 1-3, pp. 147-158, 2010.

[125] E. Horváthová, D. Slameňová, L. Hlinčíková, T. K. Mandal, A. Gábelová, and A. R. Collins, "The nature and origin of DNA single-strand breaks determined with the comet assay," Mutation Research, vol. 409, no. 3, pp. 163-171, 1998.

[126] H. Samavat and H. Mozdarani, "Chromosomal aberrations in Iranian radiation workers due to chronic exposure of Xirradiation," International Journal of Low Radiation, vol. 1, no. 2, pp. 216-222, 2004.

[127] J. M. Kauffman, "Radiation Hormesis: demonstrated, deconstructed, denied, dismissed, and some implications for public policy," Journal of Scientific Exploration, vol. 17, no. 3, pp. 389-407, 2003.

[128] M. J. Muñoz, A. López-Cortés, I Sarmiento, C. Herrera, M. E. Sánchez, and C. Paz-y-Miño, "Genetic biomonitoring of individuals exposed to ionizing radiation and the relationship with cáncer," Oncología, vol. 18, no. 1, pp. 75-82, 2008.

[129] N. Bayo, "Reacción celular ante la radiación," Radiobiología, vol. 1, no. 1, pp. 9-11, 2001.

[130] B. Leffon, B. Perez-Candahía, J. Loueiro, J. Mendez, and E. Pásaro, "Papel de los polimorfismos para enzimas de reparación en el daño del ADN inducido por estierno y estireno-7, 8-óxido," Reviews in Toxicology, no. 21, pp. 92-97, 2004.

[131] E. L. Goode, C. M. Ulrich, and J. D. Potter, "Polymorphisms in DNA repair genes and associations with cancer risk," Cancer Epidemiology Biomarkers and Prevention, vol. 11, no. 12, pp. 1513-1530, 2002.

[132] M. Díaz-Valecillos, J. Fernández, A. Rojas, J. Valecillos, and J. Cañizales, "Chromosome alterations in workers exposed to ionizing radiation," Investigacion Clinica, vol. 45, no. 3, pp. 197-211, 2004.

[133] F. Zakeri and T. Hirobe, "A cytogenetic approach to the effects of low levels of ionizing radiations on occupationally exposed individuals," European Journal of Radiology, vol. 73, no. 1, pp. 191-195, 2010.

[134] H. E. Jiliang, C. Weilin, J. Lifen, and J. Haiyan, "Comet assay and cytokinesis-blocked micronucleus test for monitoring the genotoxic effects of X-ray radiation in humans," Chinese Medical Journal, vol. 113, no. 10, pp. 911-914, 2000.

[135] L. Hagmar, S. Bonassi, U. Strömberg et al., "Chromosomal aberrations in lymphocytes predict human cancer: a report from the European study group on cytogenetic biomarkers and health (ESCH)," Cancer Research, vol. 58, no. 18, pp. 4117-4121, 1998.

[136] R. J. Albertini, D. Anderson, G. R. Douglas et al., "IPCS guidelines for the monitoring of genotoxic effects of carcinogens in humans," Mutation Research, vol. 463, no. 2, pp. 111$172,2000$. 

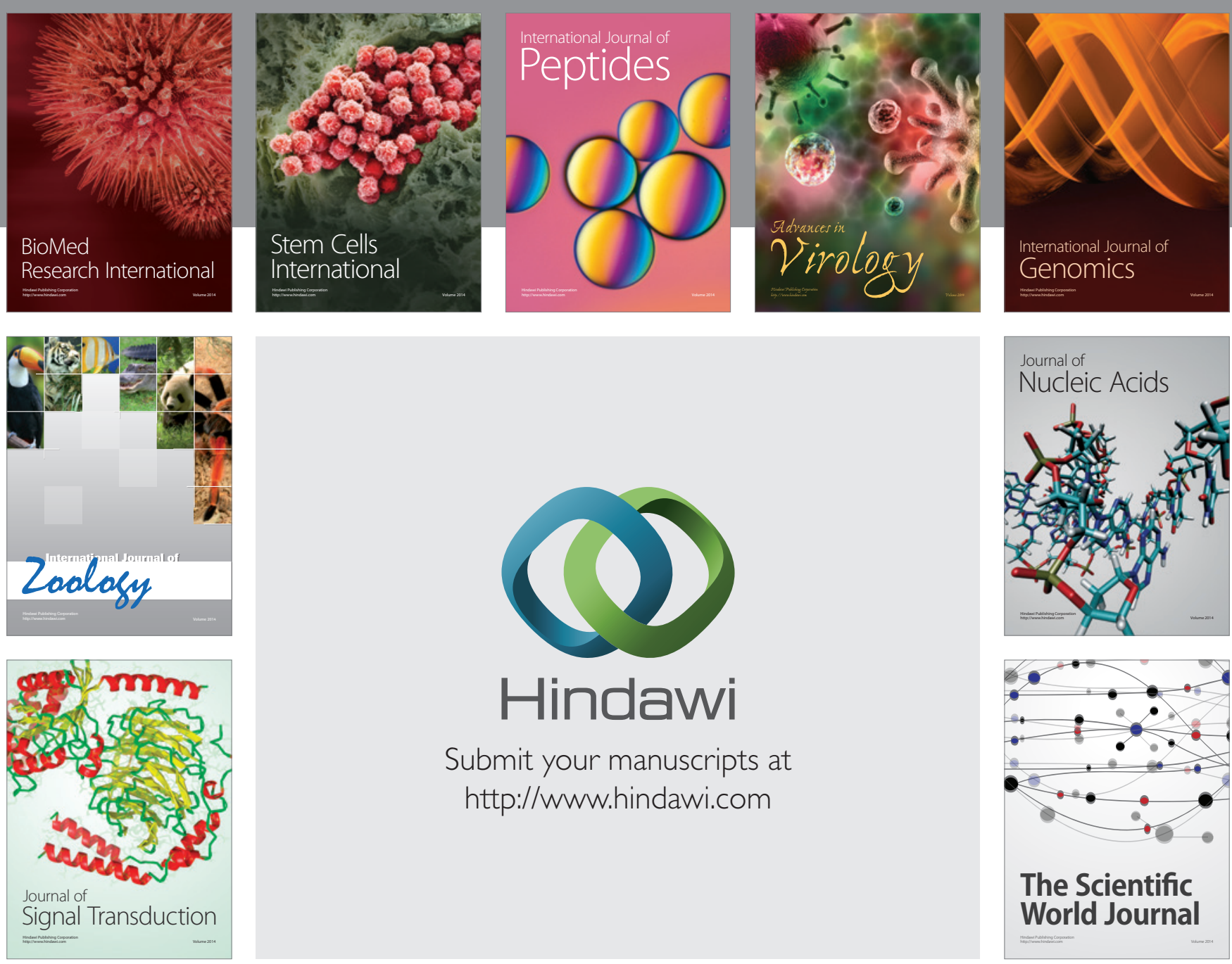

Submit your manuscripts at

http://www.hindawi.com
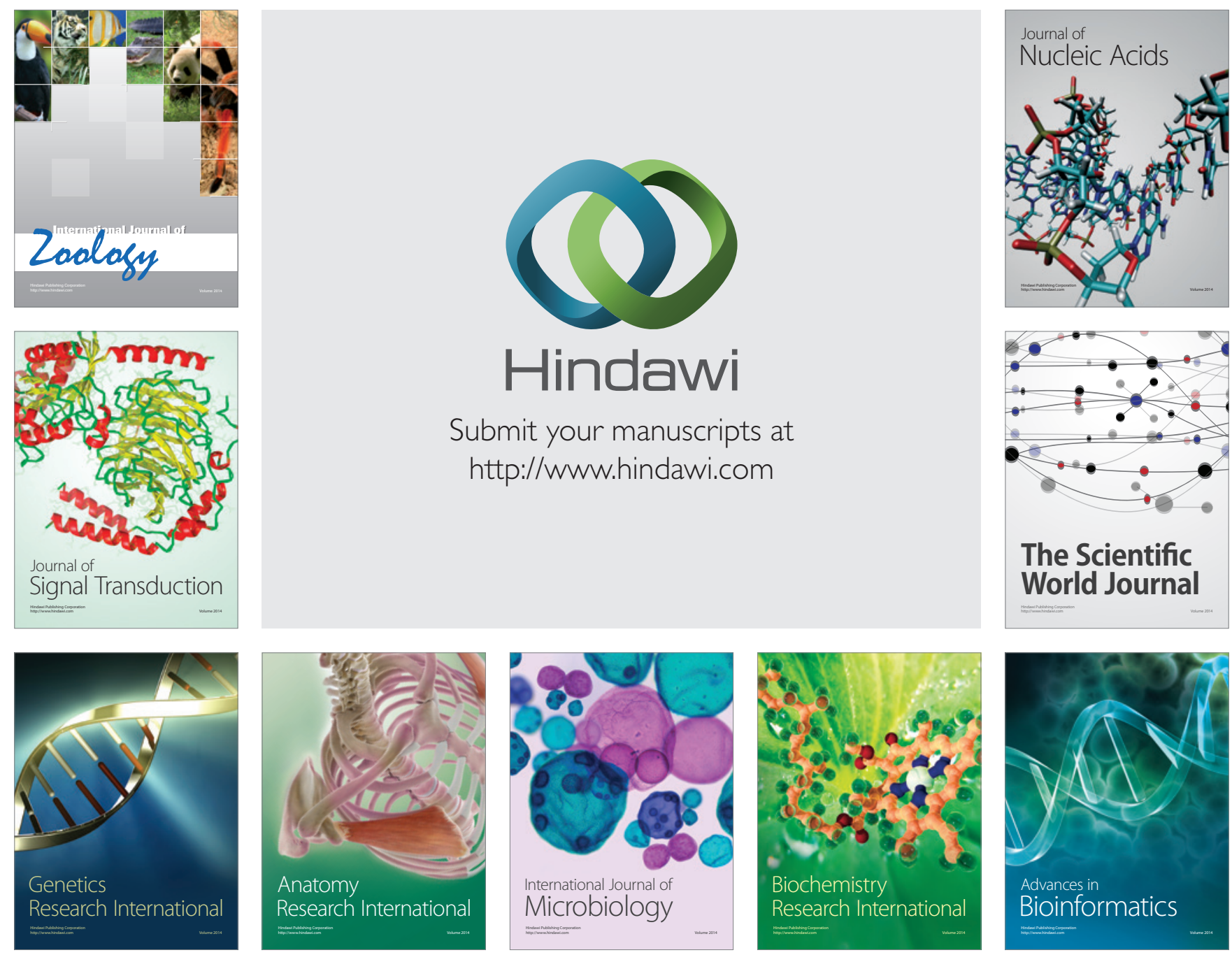

The Scientific World Journal
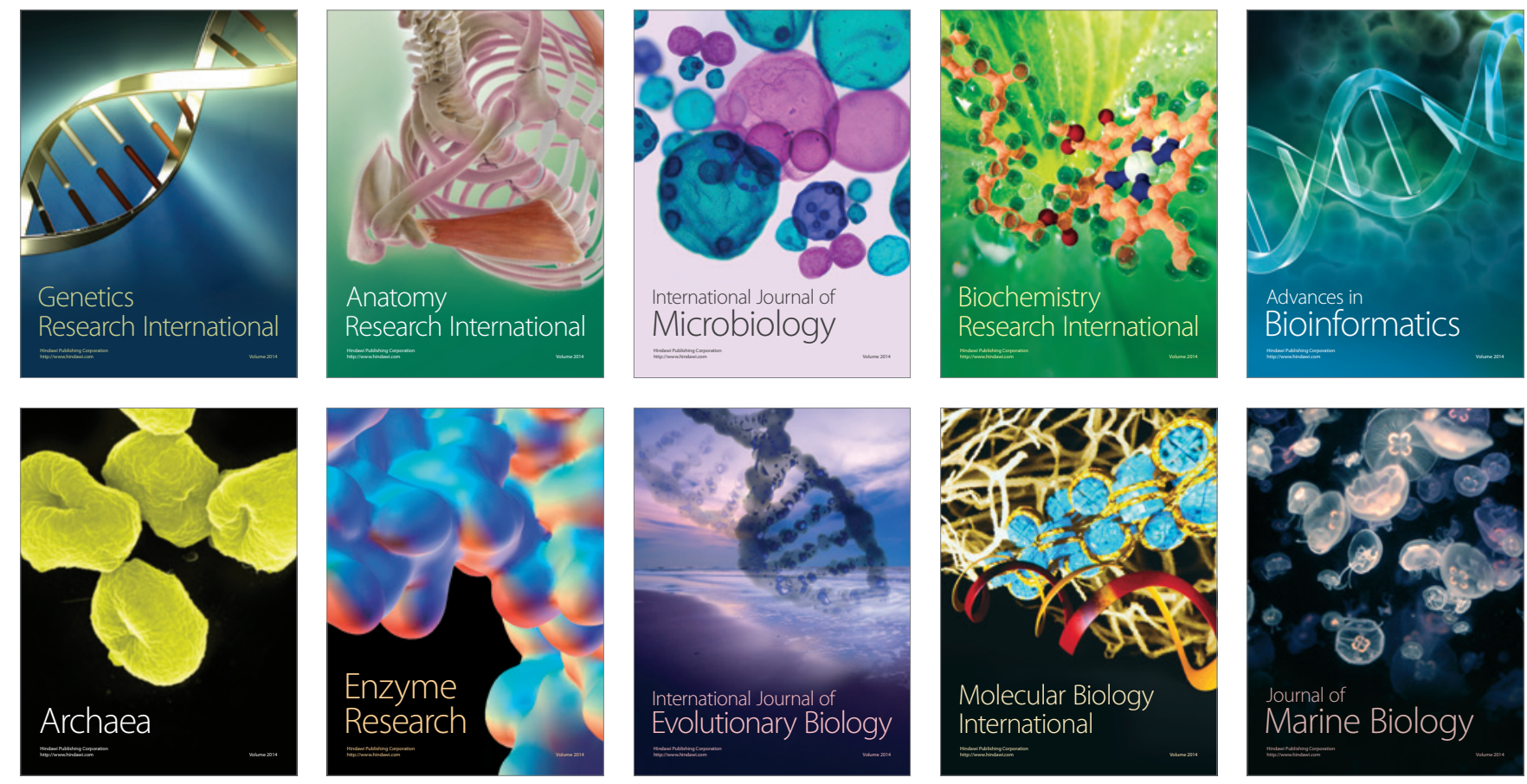